DOI: https://doi.org/10.32839/2304-5809/2019-2-66-54

UDC 6-631.635

Bugaenko Irina

ME "Kyivblahoustrii"

\title{
ASPECTS OF FORMATION AND DETERMINATION OF THE STATUS OF PROTECTIVE ZONES IN THE SYSTEM OF REGISTRATION AND ACCOUNTING OF NATIONAL NATURAL PARKS OF UKRAINE
}

Summary. The article describes the existing principles and approaches that are used to formthe ecological and territorial resource during the creation of the NPP, and also analyzes the reasons why the public initiatives aimed at preserving natural territories are not being implemented. The problems of legislative maintenance of the territory accounting process, lack of agreement of actions of various branches of executive government, inconsistency of land and environmental legislation with regard to the creation, registration and implementation of environment conservation measures in the territories of the National Natural Parks of Ukraine with the examples given were raised. It was found that design decisions, as well as accounting and registration of the NFP territories are outdated and ineffective, and some cadastral systems have shown their inability to perform the national registration functions with respect to the NPP.

Keywords: nature reserve fund, national natural park, functional zones, map-scheme, Minpryrody, State Land Cadastre.

Бугаєнко I.C.

КП «Київблагоустрій»

\section{АСПЕКТИ ФОРМУВАННЯ ТА ВИЗНАЧЕННЯ СТАТУСУ ОХОРОННИХ ЗОН В СИСТЕМІ РЕССТРАЦІЇ ТА ОБЛІКУ НАЦІОНАЛЬНИХ ПРИРОДНІХ ПАРКІВ УКРАЇНИ}

Анотація. Сьогоденні потреби суспільства все більше повертаються до цінності природи, як основного чинника людського життя. Через високий рівень забруднення атмосферного повітря в Україні кожних дві години помирають 3 людини, Україна займає останні місця серед країн Свропи по кількості природоохоронних територій тому потреба у створенні об'єктів природно-заповідного фонду стає на перший план. Розвиток заповідної справи, створення нових заповідних об'єктів є практичним втіленням екологічної політики Держави в частині збереження унікальних природних ландшафтів. У статті описані існуючі принципи та підходи, які використовуються для формування еколого-територіального ресурсу під час створення НПП, а також проаналізовані причини, чому громадські ініціативи, спрямовані на збереження природних територій, не виконуються. Проблеми законодавчого забезпечення процесу обліку території, відсутність узгодження дій різних гілок виконавчої влади, неузгодженість земельного та екологічного законодавства щодо створення, реєстрації та впровадження природоохоронних заходів на територіях Національних природних парків наведених прикладів. Встановлено, що проектні рішення, а також облік і реестрація територій ПЗФ застарілі та неефективні, а деякі кадастрові системи показали свою нездатність виконувати фрункції національної реєстрації по відношенню до НПП. У заключній частині статті уточнюеться необхідність внесення термінових змін до законодавчих актів, зміна підходів до формування та ведення державної реєстрації території; інакше загроза втрати національних природоохоронних об'єктів може стати величезною. Вона також пояснюе необхідність створення ефективного інструменту ГІС, який дозволить Вам об'єднати всю інформацію, необхідну для прийняття управлінських рішень стосовно національних парків в рамках одніеї платформи.

Ключові слова: природно-заповідний фонд, національний природний парк, функціональні зони, картосхема, Мінприроди, Державний земельний кадастр.

$\mathrm{U}$ kraine has every opportunity to implement anational ecologically balanced policy. Expansion of the conservation areas is a requirement of today and,ultimately, it is the State policy that three decades ago became determining for the most leading countries of the world. Expansion of the territories of the Nature Reserve Fund (NPF) is a direct obligation of Ukraine in accordance with the Association Agreement and other international instruments. About $18 \%$ of the territory of the European Union States has a special conservation status. In Ukraine, this figure is about $6 \%$ against the total territory of the State. This is the lowest figure in Europe, and it is necessary to remedy the situation quickly. We have very little time left to repair the lost and bring environmental legislation to the first stages of further development of the country. The successful expansion of the conservation areas is possible only with the establishment of constructive cooperation among the administrations of the National Natural Parks (NPP), scientists - ecologists, public organizations, local authorities, and executive bodies $[1 ; 2]$.

The process of formation, registration and conservation of NPP territories is a complex process which has a number of problems.

The initiators of the NPP creation areconcerned citizens and scientists - ecologists, who appeal with a proposal and accumulatedmaterials to the Ministry of Ecology and Natural Resources of Ukraine (Minpryrody) to preserve these territories by creating an NPP. Minpryrody considers this request, and if it is approved, it takes into account the accumulated materials and, by consolidated efforts, form the territories that should be part of the future NPP. 
On the basis of the accumulated materials, Minpryrody prepares atentative scheme with the areas of the territory of the future NPP. Such schemes are based on tourist maps, topographic maps of the Soviet era -in scale 1:50,000 and 1:100,000. They are approved by local authorities, executive bodies, owners of the territories that are part of the NPP.

If the scheme is approved, Minpryrody prepares a draft of the Presidential Decree "On the Establishment of a National Natural Park". The President makes a decision and signs the Decree. The only technical information contained in the Presidential Decree is the total area of the future NPP, and the list of territories to be removed for conservation. The map scheme from the decree is not published and is in fact an auxiliary document, which is kept in the archives of the Presidential Administration. On the map scheme, which forms the basis of the Presidential Decree (Fig. 1), contains the indicative boundaries of the NPP, the location of the NPP, the list of territories that should be part of it with the areas are specified. Also, the map scheme should mandatorilycontain an agreement with the landowners the territory is withdrawn from to create the NPP [3].

All further work on the NPP creation should be carried out on the basis of the Presidential Decree, the ratio of the areas of a NPP on the map and the area of the Decree, according to the analysis, is inconsistent by an average of $8 \%$, which in turn leads to misunderstandings in the future.

Bureaucratic red tape does not end after the publication of the Presidential Decree on the establishment of an NPP. Since according to the Law of Ukraine "On the State Land Cadastre"- a land plot (NPP) should be considered formed from the moment when it got a cadastral number assigned [4].
Registration of the NPP in the system of the State Land Cadastre of Ukraine takes place after the development of the land management plan for the organization and establishment of boundaries between the territories of the nature reserve fund and of other environment conservation, health improving, recreational, historical and cultural, forestry purposes, lands of the water fund and water protection zones, restrictions on land use and their regimen-forming objects (land management plan). State registration of the boundaries of the NPP territory is carried out based the land management plan drawn up and approved as prescribed by the law, then the NPP territory boundaries are state registered, which is subject to the Law of Ukraine "On State Land Cadastre".

It became known from the letters of Minpryrody that there is no NPP in the country registered in the SLC as a whole. They are registered as separate plots of land - i.e. partially. No NPP is registered in the SLC in its entirety, as stated in the Presidential Decree.

The first problem: it is a quite long period of time since the request of the society for assigning the conservation status of the NPP to the territory to the actual moment of its acquisition and registration of a new NFP facility.

The consequence of this problem is the total privatization of land, for other intended purpose, although according to the Presidential Decree, this territory is NPP - economic zone "NPP Dvorichnyansky"- other landowners within the NPP. In 2016 land plots were registered in the SLC (Fig. 2) intended forcommercial farming. Analysis of the territory state and detection of deficiencies in the land use system of the territory of NPP Dvorichnyansky and the problems with its adja-

Національний природний парк "Гомільшанські ліси" Функціональне зонування

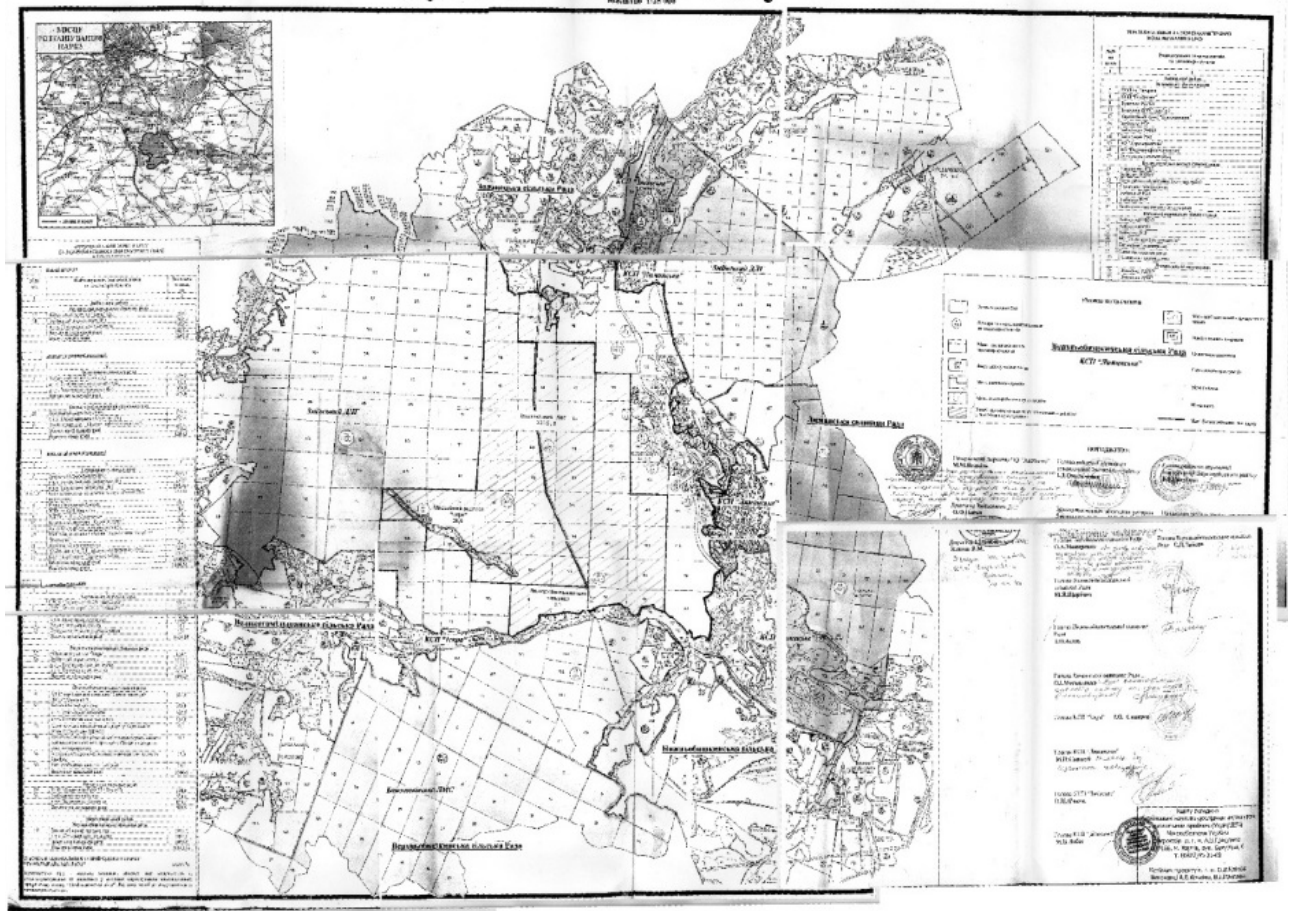

Figure 1. The map scheme, which formed the basis of the Presidential Decree "On the Creation of the National Park «Homilshanski forests»" 

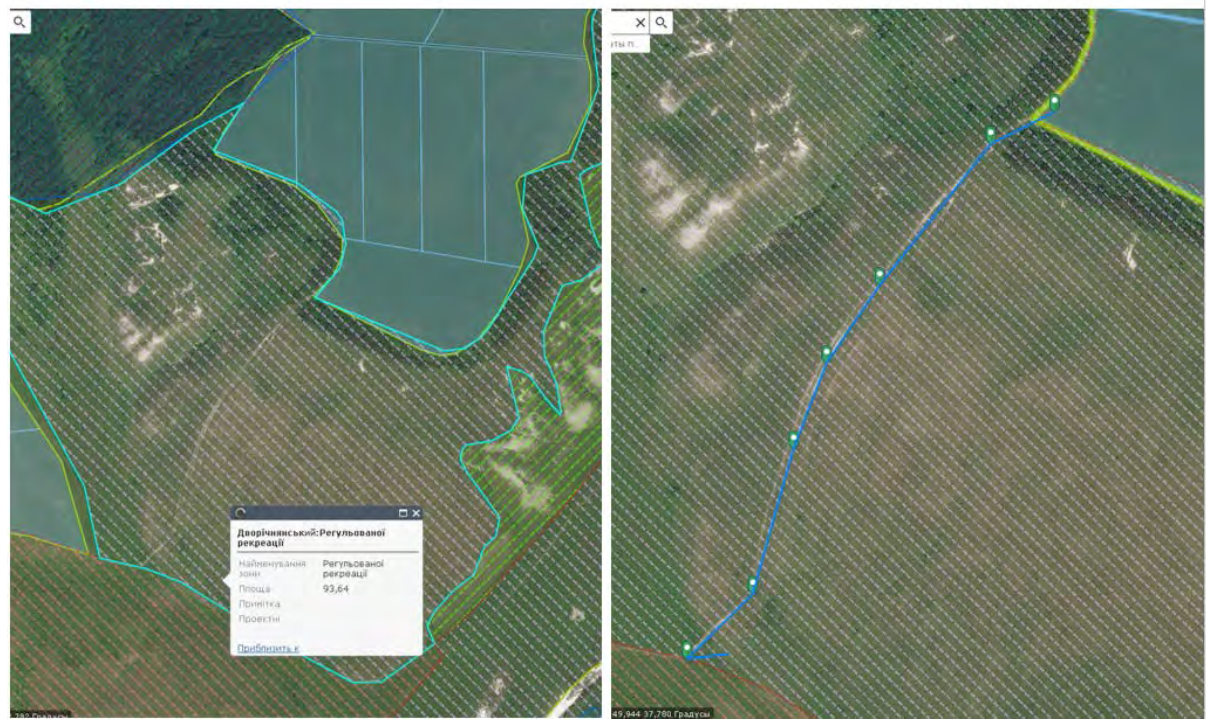

Figure 2. Analysis of the territory state and detection of deficiencies in the land use system of the territory of NPP Dvorichnyansky

cent land users showed as follows: land plots of other owners are accessed through the NPPregulated recreationzone, thus violating the regime of its use in accordance with the law of Ukraine "On the Nature Reserve Fund»

An important aspect in the NPP formation is the plan of territory management in accordance with Article 21 of the Law of Ukraine "On the Nature Reserve Fund of Ukraine" - “...taking into account environment conservation, health improving, scientific, recreational, historical and cultural and other values of natural complexes, facilities, their features, in the territory of the NPP a differentiated regime for their conservation, reproduction and use in accordance with functional zoning shall be established". There are four functional zones in the NPP: the conservation zone, the zone of regulated recreation, stationary recreation, and the economic zone (Table $1 b)$. The most severe regime iskept in the conservation zoneand regulated recreation zone - they are considered to be the most valuable.

According to Article 44 of the Land Code of Ukraine, the NPP belongs to the category of lands of the nature reserve fund of Ukraine [8], and in accordance with the Order of the State Committee on Land Resources of Ukraine No. 548 dated July 23, 2010,"On Approval of the Classification of Types of Intended LandUse" - NPPs are included in Section "C" code 4.03 (Table 1a).
The difference in the approaches of registration of one NPP territory by the central executive bodies leads to misunderstandings and significant violations of environmental legislation.

The next problem is the lack of a system for NPPaccounting. The Ecological Cadastreregardingaccounting of NPP facilities is not maintained, and all management decisions are not reflected in the single register of Minpryrody, and they have only the form of statistical reporting. Minpryrody does not have an electronic system for managing the territories and does not use modern monitoring capabilities to prevent violations and preserve the national heritage of the State.

Approaches to the formation of the territory and inclusion of more than $43 \%$ of the entire territory of the NPP to the economic zoneremainuncleared by the leadership of the Minpryrody, which leaves NPP zoning to the mercy of designers.

Conclusions and proposals. The investigation and comparison of land legislation, namely, the Land Code of Ukraine, the Law of Ukraine "On Land Management", the Law of Ukraine "On State Land Cadastre" and environmental legislation the Law of Ukraine "On the Nature Reserve Fund of Ukraine" in terms of establishing the registration and implementation of environment conservation measures in the NPP territories of Ukraine revealed a number of differences in the system of

Table 1

\begin{tabular}{|c|c|}
\hline Registration of land in the SLC & Registration of land in the Ecological Cadastre \\
\hline $1 \mathrm{a}$ & $1 \mathrm{~b}$ \\
\hline $\begin{array}{l}\text { On Approval of the Classification of Types of Intended } \\
\text { Land Use }\end{array}$ & $\begin{array}{l}\text { Law of Ukraine "On the Nature Reserve Fund } \\
\text { of Ukraine" }\end{array}$ \\
\hline $\begin{array}{l}\text { Section "C". } \\
\text { Lands of natural reserve fund and other environment } \\
\text { conservation purposes }\end{array}$ & $\begin{array}{l}\text { Article } 21 \text {.Territory structure and requirements } \\
\text { for the conservation of natural complexes and facilitiesof } \\
\text { national natural parks }\end{array}$ \\
\hline \multirow{4}{*}{$\begin{array}{l}04.03 \text { For the conservation and use of national natural } \\
\text { parks }\end{array}$} & Conservation zone \\
\hline & Regulated recreation zone \\
\hline & Stationary recreation \\
\hline & Economic zone \\
\hline
\end{tabular}


NPP territoryregistration in the Land and Ecological Cadastres. Namely - according to the Land Law, the intended use of the NPP territory has one code in accordance with the Order of the State Committee on Land Resources of Ukraine No. 548 dated July 23, 2010, "On Approval of the Classification of Types of Intended Land Use" - 04.03 for the conservation and use of national natural parks. At the same time, environmental legislation distinguishes the NPP territory by separate functional zones with different status of protection and use.

The lack of interrelations with various executive bodies leads to creation of bureaucratic red tapeon the way toward the establishment and assignment of aspecial protective statusto certain territories.

- the lack of interaction between the Cadastresleads to registration of land plots, within the NPPboundaries, havingdifferent intended purpose, which leads to the loss of the NPPnatural component.

No NPP has got its boundaries registered in the State Land Cadastre of Ukraine for all years of independence.

To resolve the above-mentioned problems, it is necessary to propose an effective mechanism for merging all types of Cadastres to prevent the loss of the State's most valuable land, this will reduce the time of registration of the territory in the State Land Cadastre and will not allow officials of various branches of government to create precedents for the emergence of such a phenomenon as disputable territories, which in various Cadastres are accounted for using different intended purposes. It should also be noted that it is necessary to introduce appropriate changes to land legislation in terms of expanding the classifier of the types of NPP functional zones to establish zoning of the territory of the NPP facilities in accordance with the Law of Ukraine "On Nature Reserve Fund". It should be borne in mind that different departments perform essentially the same design work twice (the territory management plan and the draft for land plot allocation for the NPP), due to inconsistency in design decisions, the State Budget spends considerable money while not having an impact in terms of environmental policy. The statistics on the consideration of court cases regarding disputable land plots from year to year are only increasing, and this trend is threatening, since it is not always possible for the NNP administrations and Minpryrody to make the Judicial Themis to decide in their favor.

Therefore, management decisions regarding the introduction of mechanisms for merging into a single cadastral system using GIS technologies should be made as soon as possible. It is this instrument that will be able to put accounting of the territory of Ukraine and its intended use in order, as well as to close the door on the loss of the national heritage of the State.

\section{References:}

1. Association Agreement between Ukraine, on the one hand, and the European Union, the European Atomic Energy Community and their member states, on the other hand. No. 72/14-612/1-2980 dated November 30, 2015.

2. Official web-site of the Ministry of Ecology and Natural Resources of Ukraine. URL: https://menr.gov.ua

3. Presidential Decree No. 1047/2004 dated September 6, 2004 "On the Establishment of the National Nature Park «Homilshanski Forests»".

4. Law of Ukraine "On State Land Cadastre" dated June 4, 2017 No. 3613-17. URL: http://zakon2.rada.gov.ua/laws/ show/3613-17

5. Law of Ukraine "On Land Management” dated June 10, 2017, No. 858-15. URL: http://zakon2.rada.gov.ua/laws/ show/858-15

6. Official web-site of NPP "Halytsky". URL:http://www.halychpark.if.ua

7. Public Cadastre Map of Ukraine. URL: http://map.land.gov.ua/kadastrova-karta

8. Land Code of Ukraine dated September 28, 2017, No. 2768-14. URL: http://zakon3.rada.gov.ua/laws/show/2768-14

9. Order of the State Committee on Land Resources of Ukraine No. 548 dated July 23, 2010, "On Approval of the Classification of Types of Intended Land Use". URL: http://zakon5.rada.gov.ua/laws/show/z1011-10

10. Law of Ukraine "On the Nature Reserve Fund of Ukraine" dated September 3, 2017, No. $2456-12$. URL: http://zakon3.rada.gov.ua/laws/show/2456-12

11. Order of the Ministry of Ecology and Natural Resources of Ukraine No. 245 dated July 6, 2005 "On the Regulations on the Management Planfor the Territory of the National Natural Park, Conservation, Reproduction and Recreational Use of Its Natural Complexes and Territories".

12. Management plan for the territory of NPP "Podilski Tovtry". URL: http://tovtry.com/ua/index.html 